\title{
Summary
}

CHALLENGING ISSUES RELATING TO COMPREHENSIVE EXAMINATION IN MOTOR VEHICLE INJURIES: FORENSIC MEDICAL ASPECTS

Zaritskyi H.

Key words: forensic medical examination, motor vehicle injury, comprehensive examination, damage.

Motor vehicle traumas are among the most common causes of injury both in Ukraine and around the world. Comprehensive examinations enable investigating and judicial authorities to investigate and detect crimes in cases of motor accident. The purpose of the study was to identify the most common challenging issues arising during the complex expert examinations traumas caused by motor vehicle accidents (MVA) and the ways to solve them by analyzing data obtained from forensic examinations of non-survivors in motor vehicle accidents in Ukraine. Results and discussion. According to 45 complex examination reports from the State Institution «Main Bureau of Forensic Medical Examination of the Ministry of Health of Ukraine» it was impossible to identify the position of the victims at the moment of trauma (and to identify the places the victims set in the car salon) due to the lack of primary data in $20 \%$ of the cases studied; and in only 5 cases it was possibility to establish the position of the victims at the moment of injury. Determining the location of the victim in the car, pedestrian, etc. can be only identified by characteristic and specific injuries, which are not always paid attention during the initial examination of cadavers. A lot of medical records can omit the description of some injuries (size, localization, shape, morphological features, etc.) or do not provide complete information that impedes the investigative of motor vehicle accidents. Another cause to identify the position of MVA non-survivor is inability to indicate the mechanism and sequence of damage to the car during the auto-technical expert examination. Conclusion. The study has shown that the main factors impeding the MVA investigation and clarifying the picture of event are: violation of the «Rules for conducting forensic expert examination of corpses in the forensic examination bureau» during the initial examination; the absence or poor quality description in the protocols and guidelines for the inspection of the accident scene, including physical evidence and the condition of the vehicle; the inability to establish the nature of injuries on the body of victims or non-survivors and damage to vehicles due to delays in the investigation of crimes; drawbacks in filling in and keeping medical documentation: absence or incomplete description of damage (size, shape, location, morphological features, etc.).

DOI 10.31718/2077-1096.20.3.196

UDC: [616-099-02:543.272.455]-092.9-07:616.15- 078: [577.175.823:577.112.387].088.6

Kolisnyk I.L., Bagmut I.Yu.

\section{MORPHOFUNCTIONAL STATE OF HEPATOCYTES UNDER THE EXPOSURE TO SODIUM FLUORIDE}

Kharkiv Medical Academy of Postgraduate Education

The article provides the data on the morphofunctional state of hepatocytes in the liver of white rats under the subtoxic action of sodium fluoride. Mature rats of the Wistar population $(N=17)$, weighing 180-210 g, were intragastrically injected with aqueous solutions of sodium fluoride in a dose of 1/10 $L D_{50}$ at the ratio of $20 \mathrm{mg}$ I $\mathrm{kg}$ of animal body weight daily. The subacute experiment lasted 60 days. Studying hepatocytes in the rat liver and assessing their morphological rearrangement at the subcellular level of organization was carried out by electron microscopy. The study of ultrastructural organization of the liver under the influence of sodium fluoride revealed changes in the submicroscopic architecture characteristic of the development of dystrophic processes. Prolonged intoxication with sodium fluoride caused a number of changes in the liver ultrastructurer, manifested by the development of intracellular edema in hepatocytes, swelling of mitochondria, changes in the density of their matrix, partial reduction and loss of cristae, vacuolization and expansion of the cisterns of the granular endoplasmic reticulum, an increase in the number of primary lysosomes, redistribution chromatin of the nucleus and a decrease in the number of ribosomes and glycogen granules. These changes indicate a disruption of bioenergetics of hepatocytes associated with the mitochondrial apparatus and the development of hypoxic processes, which lead to a decrease in the activity of redox reactions occurring at the level of intracellular membranes and organelles.

Key words: sodium fluoride, hepatocytes, electron microscopy, intoxication, lipid peroxidation.

The study was conducted in accordance with the research plan of Kharkiv Medical Academy of Postgraduate Education, the Ministry of Public Health of Ukraine, and is a part of the research project of the Department of Clinical Pathophysiology, Topographic Anatomy and Operative Surgery "Pathophysiological mechanisms of the action of radiotoxins on the body and the principles of early diagnostics and correction" (state registration number 0117U000589, 2017-2021).

\section{Introduction}

Fluorine compounds are widespread in nature and known as industrial pollutants [1]. Fluorine does not exist in nature in a free state, but it forms inorganic and organic complex compounds, fluo- 
rides, whose content in the Earth's crust is approximately $0.06-0.09 \%$. It is known that low concentrations of fluoride are necessary for normal growth and development of the body. However, in the case of excessive intake, significant dysfunctions of vital organs, cell damage, and necrosis occur [1]. Fluoride ion as a chemical agent affects metabolism that is manifested by functional and structural changes. The damaging factors include several pathogenetic mechanisms, and in particular: disruption of the energy supply of the processes taking place in cells and damage to membrane structures and enzyme systems of cells [2]. Sodium fluoride is a metabolic poison and primarily has a membrane damaging effect. In chronic chemical stress, systemic changes in the functional state of the body occur at all levels of integration, or a syndrome of an environmentally determined decrease in body resistance. The development of this syndrome results in the effect of chemical modification that is, an increase in the number of diseases of certain organs and the aggravation of their course against the background of a decrease in immune parameters and disrupted protective and adaptive capabilities [2]. With an increase in the amount of phosphorus-containing detergents in the body, diseases of the central nervous system, endocrine system, organs of the digestive system, and in particular, the liver, occur. The experiments have demonstrated that in the prolonged exposure to synthetic phosphorus-containing detergents leads to protein and fatty degeneration in the liver and lipid peroxidation products in the blood [3].

The aim of the study was to investigate the morphofunctional state of hepatocytes in the liver of white rats under the exposure to subtoxic effect of sodium fluoride.

\section{Material and methods of the research}

Mature Wistar rats $(\mathrm{N}=17)$, weighing 180-210 $\mathrm{g}$, were given intragastrical injections with aqueous solutions of sodium fluoride in a dose of $1 / 10 L D_{50}$ at the ration of $20 \mathrm{mg} / \mathrm{kg}$ of animal body weight daily. The subacute experiment lasted 60 days, and at the end the animals were decapitated. When working with the test animals, we adhered all the requirements of the "European Convention for the Protection of Vertebrate Animals Used in Experiments and Other Scientific Purposes" (Strasbourg, 1986), Law of Ukraine No. 3447-IV as of February 21, 2006, "On the Protection of Animals from Cruelty".

To study hepatocytes in the rat liver and to assess their morphological rearrangement at the subcellular level of organization, we used electron microscopy. We fixed the pieces of the studied liver samples sized $1 \mathrm{~mm}^{3}$ in a $2.5 \%$ solution of glutaraldehyde on $0.1 \mathrm{M}$ phosphate buffer of $\mathrm{pH} 7.2$ and in $1 \%$ Palladian osmium fixative. After dehydration in solutions with increasing concentration of ethanol and absolute acetone, the material was embedded into epon-araldite mixture. By ultramicrotome we cut the preparations into semi-thin sections of 1-2 $\mu \mathrm{m}$, then stained with methylene blue, and studied at the light-optical level. Then after targeted sharpening of the blocks, we obtained ultrathin sections, which were contrasted with uranium and lead salts according to Reynolds' staining technique. We studied the samples under an electron microscope at an accelerating voltage of $75 \mathrm{kV}$.

\section{Results and Discussion}

The liver is the main organ of xenobiotic metabolism. Electron microscopy of the liver taken from test animals showed a pronounced heterogeneity of hepatocytes. Along with the usual "dark" and "light" hepatocytes, "light" cells of much larger sizes were found out. These cells seemed to squeeze smaller "dark" hepatocytes. A control study of semi-thin sections made from the same blocks, using a light microscope, revealed many large cells, significantly larger than the normal ones, observed in the control group of animals, among which "dark" hepatocytes of relatively small sizes were localized. On specimens prepared by the standard histological methods for light microscopy, "light" cells were not detected. Clearing of the cytoplasm was most likely associated with the phenomena of intracellular edema, which is a sign of the disrupted water-electrolyte balance and the permeability of the cytoplasmic membranes.

The granular endoplasmic reticulum was moderately developed, but its cisterns were sharply expanded and formed large transparent vacuoles. In these cells, significant hypertrophy of the cisterns of the smooth endoplasmic reticulum was observed. The nuclei of hepatocytes remained oval, their chromatin was unevenly distributed. Lumps of chromatin were concentrated mainly along the nuclear membrane. Karyolemma was significantly loosened; the perinuclear spaces were enlarged. The lamellar cytoplasmic Golgi complex was moderately hypertrophied and consisted of stacks of smooth membranes surrounded by a large number of vesicles of various sizes. The nuclear membrane of hepatic cells became convoluted and formed folds with deep invaginations.

These changes indicate a disruption of bioenergetics of hepatocytes associated with the mitochondrial apparatus and the development of hypoxic processes, which lead to a decrease in the activity of redox reactions occurring at the level of intracellular membranes and organelles [5]. A consequence of these disorders is a decrease in the synthetic activity of hepatocytes that is structurally expressed in vacuolization of the cisterns of the granular endoplasmic reticulum, in a sharp decrease in the number of ribosomes associated with its membranes, freely lying in the cytoplasm. Electron microscopy revealed the presence of a large number of primary lysosomes at various stages of their activity, as well as autophagosomes: this indirectly indicates an increase in the concentration of metabolites in the cytoplasm of hepatocytes. A characteristic feature of the submicroscopic organi- 
zation of the liver under the influence of sodium fluoride is a higher intensity of changes in organelles in the cells localized in the areas adjacent to large blood vessels and less pronounced disturbances in the ultrastructures of liver cells located in the peripheral regions [6]. A manifestation of a particularly severe reaction on the part of hepatocytes is the presence of the edematous and cleared ones, with excessively swollen mitochondria, vacuolated endoplasmic reticulum, "light" hepatocytes, which seem to squeeze "dark" cells. In the cytoplasm of these cells, we found the foci of lysis of the nuclear membrane, outer membranes and cristae of mitochondria, the appearance of autophagosomes, which indicates the exhaustion of compensatory, synthetic and reparative reserves by intracellular structures and the development of catabolic processes at the membranous and macromolecular levels. The revealed submicroscopic disorders of the endothelial cells of sinusoidal capillaries indicate a disruption of the capillary wall permeability for electrolytes and metabolites. A sharp fall in the number of micropinocytic vesicles in the cytoplasm of endotheliocyte processes indicates a decrease in the intensity of transcellular transport of substances through the capillary wall [7]. It should be emphasized that the changes described above in the submicroscopic architecture of liver cells are mainly compensatory and adaptive and their intensity lies within physiological limits. They are reversible after removal of the pathogenic factor. At the same time, the signs of the development of a destructive process begin to appear in the individual cells [8].

The main enzyme systems involved in the conversion of xenobiotics are localized in hepatocytes, where, as a result of redox reactions and conjugation reactions, a foreign chemical is modified and eliminated by excretory systems. These enzyme systems are localized in mitochondria, microsomes, or hyaloplasm. The detoxification of chemical compounds can take place by the type of chemical oxidation, reduction, hydrolytic transformation, or by conjugation. The main laboratory carrying out these processes is the endoplasmic reticulum of liver cells, whose microsomes contain a significant amount of ribonucleic acids, phospholipids and proteins.

\section{Conclusions}

Thus, the study of the ultrastructural organization of the liver under the exposure of sodium fluoride revealed changes in the submicroscopic architecture characteristic of the development of dystrophic processes. Prolonged sodium fluoride intoxication causes a number of changes in the ultrastructure of the liver, expressed in the development of intracellular edema of hepatocytes, swelling of mitochondria, alterations in the density of their matrix, partial reduction and loss of cristae, vacuolization and expansion of the cisterns of the granular endoplasmic reticulum, an increase in the number of primary lysosomes, redistribution chromatin of the nucleus and a decrease in the number of ribosomes and glycogen granules. These changes indicates the disruption of bioenergetics of hepatocytes associated with the mitochondrial apparatus and the development of hypoxic processes that lead to a decline in the activity of redox reactions occurring at the level of intracellular membranes and organelles [9].

The damaging membrane trophic activity of free radicals and lipid peroxidation products develops in two main directions. The first is a disruption of the barrier properties of membranes. It is viewed as an acute injury that leads to cell death. The most important consequence of lipid peroxidation in membranes is an increase in their permeability for protons and calcium ions, a loss of membrane electrical stability that is manifested by a decrease in the electrical breakdown potential of the membrane. These changes can result in cell death. The second is a disruption of the physicochemical state of the lipid bilayer of membranes that is considered as their "soft" modification and leads to the development of chronic pathological conditions. A change in the matrix properties of membranes can be due to a reduced microviscosity of the lipid phase, an increase in negative charge, polarity, and a decrease in the hydrophobic volume.

Increased free radical processes can develop due to a variety of chemical intoxications, physical and biological harmful effects and refer to the general nonspecific reactions of the body to the damaging effect. The activation of free radical processes and lipid peroxidation act as a universal mechanism of membrane damage and is observed in different pathological conditions, including stress factors of various nature, and aging. The products of free radical oxidation, lipid peroxidation, acting on membranes, change the viscosity of the lipid bilayer, lead to the appearance of products that quench fluorescence, reduce electrical stability, hydrophobic volume, and disrupt the ionic permeability of membranes. Further investigation of the morphometric and biochemical changes in hepatocytes under the influence of synthetic phosphoruscontaining detergents to determine the intensity of damage and the possibility of correcting these changes with hepatoprotectors seems to be clinically important.

\section{References}

1. Alekhina DA, Zhukova AG, Sazontova TG, Alekhina DA, Zhukova AG Sazontova TG Nizkaya doza ftora vliyayet na AG, Sazonlikal'noy svobodnoradikal'noye okisleniye i vnutrikletochnyye zashchitnyye sistemy serdtsa, legkikh i pechen [Low dose of fluoride influences to free radical oxidation and intracellular protective systems in heart, lung and liver]. Tekhnologii zhivykh system. 2016; 13(6): 4956. (Russian).

2. Kazarina LN, Samarkina AN, Pursanova AYe. Meditsinskiye aspekty kompleksnoy profilaktiki i lecheniya flyuoroza u detey phylaxis and treatment of fluorosis in the case of children living in ende mic district]. Meditsinskiy al'manakh Medical almanac. 2015; (3): 1725. (Russian).

3. Zhukova AG, Mikhaylova NN, Yadykina TK, Alekhina DA, Gorokhova LG, Romanenko DV i dr. Eksperimental'nyye issledovaniya vnutrikletochnykh zashchitnykh mekhanizmov 
pecheni pri razvitii khronicheskoy ftoroplasticheskoy intoksikatsi [Experimental studies of intracellular liver protective mechanisms in development of chronic fluorine intoxication]. Meditsina truda i promyshlennaya ekologiya. 2016; (5): 21-4. (Russian).

4. Akimov O.Ye., Mishchenko A.V., Kostenko V.O. Influence of combined nitrate and fluoride intoxication on connective tissue disorders in rats gastric mucosa. Archives of the Balkan Medical Union. 2019; 54(3):11-15. DOI: 10.31688/ABMU.2019.54.3.03.

5. Yelinskaya A.M., Akimov O.Ye., Kostenko V.O. Role of AP-1 transcriptional factor in development of oxidative and nitrosative stress in periodontal tissues during systemic inflammatory response.

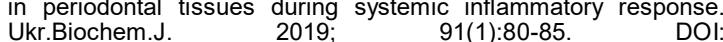
https://doi.org/10.15407/ubj91.01.080.

6. Akimov O.Ye., Kovalova I.O., Kostenko V.O. Correction of destructive changes in connective tissues of different organs during chronic nitrate and fluoride intoxication by nanosized silica oxide.
Journal of Education, Health and Sport. 2019; 9(5):547-555. DOI. http://dx.doi.org/10.5281/zenodo.3238594

7. Akimov OYe Mishchenko AV Kostenko VO Korrektsiya oksidativnogo stressa slizistoy obolochki zheludka krys enterosorbentami raznogo klassa pri khronicheskoy intoksikatsii nitratftoridom [Correction of oxidative stress in gastric mucosa of rats by enterosorbents of different classesduring chronic nitrate fluoride intoxicationl. Aktual'ni problemy suchasnovi medytsynv: Visnyk Ukrayins'koyi medychnoyi stomatolohichnoyi akademiyi. 2019; 19(2):103-106. DOI 10.31718/20771096.19.2.103. (Russian)

8. Akimov O.Ye., Kostenko V.O. Superoxide and peroxynitrite production in qastric mucosa of rats under combined nitratefluoride intoxication. Zhurnal Grodnenskoqo gosudarstvennogo meditsinskogo universiteta. 2018; 16(6):730-734. DOI: 10.25298/2221-8785-2018-16-6-730-734

\section{Рефрерат}

МОРФОФУНКЦИОНАЛЬНОЕ СОСТОЯНИЕ ГЕПАТОЦИТОВ ПОД ВЛИЯНИЕМ ФТОРИДА НАТРИЯ

Колесник И.Л., Багмут И.Ю.

Ключевые слова: фторид натрия, гепатоциты, электронная микроскопия, интоксикация, перекисное окисление липидов.

Исследовано морфофункциональное состояние гепатоцитов печени белых крыс при субтоксическом действии фрторида натрия. На половозрелых крысах популяции Вистар (N=17), массой 180-210 г, которым ежедневно внутрижелудочно вводились водные растворы фрторида натрия дозе $1 / 10$ LD 50 из расчета 20 мг/кг массы животных. Продолжительность подострого опыта составляла 60 суток. Для изучения гепатоцитов печени крыс с оценкой их морфологической перестройки на субклеточном уровне организации проводили электронно-микроскопическое исследование. Проведенное электронномикроскопическое исследование ультраструктурной организации печени при воздействии фрторида натрия выявило изменения субмикроскопической архитектоники характерные для развития дистрофических процессов. Длительная интоксикация фторидом натрия вызывает ряд изменений ультраструктуры печени, выражающиеся в развитии внутриклеточного отека гепатоцитов, набуханий митохондрий, изменении плотности их матрикса, частичной редукции и потери крист, вакуолизации и расширении цистерн зернистого эндоплазматического ретикулума, увеличении количества первичных лизосом, в перераспределении хроматина ядра и уменьшении числа рибосом и гранул гликогена. Эти изменения свидетельствуют о нарушении биоэнергетики гепатоцитов, связанной с митохондриальным аппаратом и развитием гипоксических процессов, которые ведут к снижению активности окислительно-восстановительных реакций, протекающих на уровне внутриклеточных мембран и органелл.

\section{Рефрерат}

\section{МОРФОФУНКЦІОНАЛЬНИЙ СТАН ГЕПАТОЦИТІВ ПІД ВПЛИВОМ ФТОРИДУ НАТРІЮ}

Колісник І.Л., Багмут І.Ю.

Ключові слова: фрторид натрію, гепатоцити, електронна мікроскопія, інтоксикація, перекисне окислення ліпідів.

Досліджено морфофункціональний стан гепатоцитів печінки білих щурів під впливом субтоксичних дій фториду натрія. На статевозрілих щурах популяції Вістар ( $\mathrm{N}=17)$, масою 180-210 г, яким щодня внутрішньошлунково вводились водні розчини фрториду натрію в дозі 1/10 LD 50 розрахунку 20 мг / кг маси тварин. Тривалість підгострого досліду становила 60 діб. Для вивчення гепатоцитів печінки щурів з оцінкою їх морфологічної перебудови на субклітинному рівні організації провели електронномікроскопічне дослідження. Проведене електронно-мікроскопічне дослідження ультраструктурної організації печінки під впливом фториду натрію виявило зміни субмікроскопічної архітектоніки які характерні для розвитку дистрофрічних процесів. Тривала інтоксикація фрторидом натрію викликає ряд змін ультраструктури печінки, що виражаються в розвитку внутрішньоклітинного набряку гепатоцитів, набухання мітохондрій, зміні щільності їх матриксу, часткової редукції і втрати крист, вакуолизации і розширенні цистерн зернистого ендоплазматичного ретикулуму, збільшенні кількості первинних лізосом, в перерозподілі хроматину ядра і зменшенні кількості рибосом і гранул глікогену. Ці зміни свідчать про порушення біоенергетики гепатоцітов, пов'язаної з мітохондріальним апаратом і розвитком гіпоксичних процесів, які ведуть до зниження активності окислювально-відновних реакцій, що відбуваються на рівні внутрішньоклітинних мембран і органел 